\title{
A Falsificação do Jornal Católico "O São Paulo" no Período de Redemocratização Brasileira (1982): Perspectivas e O posições*
}

\author{
Fabio Lanza** \\ José Wilson Assis Neves Júnior ${ }^{* * *}$ \\ Raíssa Regina Brugiato Rodrigues****
}

\section{Resumo}

Esta pesquisa realizou uma análise da edição falsificada do jornal católico “O São Paulo", ocorrida em 1982, ano no qual estava em curso a abertura política no país, buscando uma interpretação das reflexões de seus autores. O método utilizado foi a análise com fontes documentais, orientada por categorias analíticas. A partir das elaborações de Karl Mannheim sobre estilos de pensamento e visões de mundo, compreendeu-se que se tratava de uma tentativa de comunicação com os leitores do semanário, contestando suas publicações anteriores e apresentando perspectivas que mantinham diálogos com formas de pensamento pró-ditadura militar. Apreenderam-se, também, na edição "Mea Culpa", diferentes ideais político-ideológicos que visavam à articulação política conjunta para combater e desqualificar elementos do catolicismo libertador vinculados ao "O São Paulo".

Palavras-Chave: Pensamento Político Brasileiro. Ditadura Militar (19641985). Jornal Católico O São Paulo. Imprensa Escrita. Política Brasileira.

\footnotetext{
* Este artigo é resultado das investigações desenvolvidas no âmbito do grupo de pesquisa CNPq/UEL História, Sociedade e Religião. 0 trabalho a seguir foi construído a partir dos trabalhos de Lanza (2006); Neves Jr (2016) e Rodrigues (2018).

** Doutor em Ciências Sociais pela Pontifícia Universidade Católica (PUC-SP). Professor Associado no Departamento de Ciências Sociais da Universidade Estadual de Londrina. Coordenador do Laboratório de Estudos sobre as Religiões e Religiosidades da UEL. E-mail: lanza1975@gmail.com

*** Doutorando pelo Programa de Pós-Graduação em Ciências Sociais da Unesp/Marília. Mestre e bacharel em Ciências Sociais pela UEL. E-mail: nevesjr1991@gmail.com **** Mestre em Ciências Sociais pela UEL. Pesquisadora vinculada ao Laboratório de Estudos sobre Religiões e Religiosidades (LERR-UEL).E-mail: raissaregina.uel@hotmail.com
} 


\title{
The Falsification of the Catholic N ewspaper 0 São Paulo in The Period of Brazilian Redemocratization (1982): Perspectives and 0 ppositions.
}

\begin{abstract}
The present research realized, from the falsification of the catholic newspaper O São Paulo, that occurred in 1982, year in which political opening of the country was underway, an analyzes of that edition, searching an interpretation of their authors reflections. The utilized methodology was the documental analyzes, oriented by analytical categories. From Karl Mannheim's elaborations about styles of thinking and worldviews, it was understood as an attempt to communicate with the newspaper's readers, contesting its previously publications, and presenting perspectives that maintains dialogues with styles of thinking pro military dictatorship. It was also apprehended different political-ideological ideals in the Mea Culpa edition, that targeted the political articulation to combat and disqualify the elements of liberator Catholicism bonded to O São Paulo.
\end{abstract}

Keywords: Brazilian Political Thinking. Military Dictatorship (19641985). Catholic Newspaper O São Paulo. Written Press. Brazilian Politics.

\section{La Falsificación del Periódico Católico O São Paulo en el Período de Redemocratización Brasileña (1982): Perspectivas Y O posiciones.}

\section{Resumen}

La investigación realiza, partiendo de la falsificación del periódico católico "O São Paulo", que ocurrió en 1982, año en cuál estaba em curso la transición política brasileña, un análisis de esta edición, buscando una interpretación de las reflexiones de sus escritores. La metodología movilizada fue el análisis con fuentes documentales, orientada por categorías analíticas. A partir de las elaboraciones de Karl Mannheim 
sobre estilos de pensamiento y visiones de mundo, se percibió tratarse de un intento de comunicarse con los lectores de lo periódico, impugnando sus contenidos anteriores, y presentando perspectivas que mantienen diálogos com formas de pensamiento a favor de la dictadura militar. También se percibió diferentes ideales políticos e ideológicos en la edición "Mea Culpa", que pretendían a la articulación política conjunta para combate y descalificación de elementos del catolicismo liberador vinculados en el "O São Paulo".

Palabras clave: Pensamiento Político Brasileño. Dictadura Militar (1964-1985). Periódico O São Paulo. Prensa Escrita. Política Brasileña.

\section{Introdução}

A presente pesquisa refere-se à análise de uma edição falsificada do jornal católico "O São Paulo" (JOSP), semanário vinculado à sede de maior expressão do catolicismo brasileiro, a Arquidiocese de São Paulo ${ }^{1}$. A falsificação ocorreu no ano de 1982, período que compreende histórica, social, cultural e politicamente, a conjuntura da Ditadura Militar ${ }^{2}$ no Brasil, e o processo de abertura política do país ${ }^{3}$, ou seja, uma época em que havia mudanças políticas e sociais em curso no país.

10 arquivo contém uma edição falsificada do jornal católico “O São Paulo", e outros 154 documentos referentes à reação midiática, posterior à falsificação, de jornais e revistas nacionais e internacionais que acompanharam as investigações sobre os responsáveis pela falsificação.

2 Existe um amplo debate acadêmico a respeito da conceitualização que deve ser atribuída ao tipo de regime que caracterizou o período, que se destaca pela controvérsia do fato de ter se constituído enquanto ditadura exclusivamente militar ou se foi de fato uma ditadura civil-militar, o que implica na participação de demais segmentos da sociedade civil brasileira nos direcionamentos do regime ditatorial. Este, contanto, não é o cerne principal da pesquisa proposta.

3 Rezende (2013) aponta que o processo de abertura política brasileira ocorreu de forma lenta e gradual, enfatizando as menções realizadas pelos dois presidentes responsáveis pelo processo, os generais Ernesto Geisel (1974-79) e João Batista Figueiredo (1979-85), em garantir a incorporação, em nível nacional, dos princípios que nortearam a "revolução de 1964". 
Este estudo foi possível porque a Arquidiocese de São Paulo e o Laboratório de Estudos das Religiões e Religiosidades (LERR), vinculados ao Núcleo de Documentação e Pesquisa Histórica (NDPH) da Universidade Estadual de Londrina, preservaram e publicizaram o arquivo de matéria censurada pela ditadura militar do jornal "O São Paulo". No entanto, entre os respectivos documentos, havia o dossiê com a edição "Mea Culpa"4 - além de 154 matérias de jornais e revistas, nacionais e internacionais, que acompanharam as investigações acerca do ocorrido.

É importante destacar também que, embora, em um primeiro momento, o clero da Arquidiocese tenha apoiado o golpe militar, posteriormente mudou sua posição, e, em meio a este processo, o JOSP sofreu a ação da censura prévia de 1972 a 1978, devido ao conteúdo veiculado por suas publicações, que continham denúncias da inexistência de uma democracia de fato no país, da desigualdade econômica, das torturas e métodos violentos utilizados por grupos militares, entre outros (Lanza, 2006).

A edição "Mea Culpa”, apesar da aparência similar, divergia do conteúdo das publicações originais do semanário no período em que o jornal sofreu com a censura. Apresentava, entre outros fatores, denúncias relacionadas ao comunismo infiltrado na Igreja e admissões de culpa, ou, ainda, reflexões de membros da Arquidiocese, como é o caso de D. Paulo Arns, Arcebispo responsável pela edição do semanário na época, que teria supostamente assumido a culpa de possibilitar que o marxismo adentrasse à Arquidiocese em suas orientações ${ }^{5}$.

4 Ainda não há versão online disponível. Os documentos do acervo serão organizados e disponibilizados posteriormente ao Núcleo de Documentação e Pesquisa Histórica da UEL. 5 A falsificação da edição do semanário católico se encaixa na tendência apontada por Santos (2014) a respeito de atos de caráter terrorista encabeçados por grupos conservadores durante a abertura política, principalmente entre os anos de 1979 e 1981.0 autor estipula a ocorrência de 100 ações que se encaixam na perspectiva do terror e violência. 
Assim, a presente pesquisa estabeleceu como eixo teórico-metodológico a análise mannheimiana do "estilo de pensamento" que embasou a edição "Mea Culpa". Segundo Mannheim (1981), identificam-se na conjuntura de uma época os embates dinâmicos entre estilos de pensamento, que tanto são influenciados pelas transformações sociais quanto visam influenciá-las. 0 autor define cinco tipos classificatórios de "estilos de pensamento":

- "Conservadorismo": tem sua gênese no processo de racionalização, para ação política, de uma reação tradicionalista às proposições progressistas de uma época, tende a fundamentar-se na defesa da manutenção da ordem social e no combate às perspectivas de mudança.

- "Reformismo conservador": ataca detalhes particulares do sistema, trazendo proposições substitutivas de fatores individuais consolidados por novas demandas individuais, as quais acabam gerando "melhorias" não só para o grupo em questão como para outros.

- "Reformismo progressista": apesar de atacar o sistema todo, sua ação política tem como fundamento o combate a um fato indesejável, encontrando a necessidade de uma reforma completa do mundo para coexistir.

- "Progressismo": embasa-se na completa transformação da realidade social, propondo um conjunto amplo de mudanças que implica o rompimento do status quo para a criação de uma nova ordem social que torne possível a existência desta forma de pensar.

- “Tradicionalismo": pode permear todos os "estilos de pensamento" (apesar de apresentar maior tendência vinculativa ao conservadorismo), caracteriza-se pela forte presença de elementos da religiosidade e moralidade, comumente expri- 
mindo reflexões anacrônicas à época em defesa de uma ordem social passada.

Foram apropriadas, ainda, as contribuições pertinentes ao método de análise documental como forma de subsidiar o trato das fontes, selecionando-as de forma intencional. Segundo May (2004) esse método se refere, entre outros fatores, a um processo de investigação das relações estabelecidas entre os autores, compondo uma conjuntura específica, na qual os documentos são produzidos. Para tanto, deve-se atentar tanto à lógica de redação dos documentos, identificando a forma como os conceitos chave são significados pelo autor, ou autores, quanto aos potenciais impactos da produção deste documento para a realidade da época - a quem ele é dirigido, de que forma seria interpretado pelos grupos de oposição e apoio, entre outros.

Compreende-se, assim, que a edição apócrifa constitui um registro documental, composto por quatro laudas, que apresenta textos elaborados por indivíduos que procuraram fazer-se passar por membros da Arquidiocese no período. Portanto, isso é significativo no que se refere às perspectivas de seus autores em relação às suas formas de leitura da realidade política e social.

A compreensão do conteúdo do "Mea Culpa" abre possibilidades para o contato com as visões de mundo que seus autores e idealizadores buscavam comunicar ao público leitor do semanário. Para tanto, foram elaboradas categorias analíticas que auxiliaram na interpretação da fonte documental, sendo elas: 1) as visões de mundo do JOSP (1970-1985) e da edição "Mea Culpa" (1982), em relação à conjuntura e dos temas sócio-políticos; 2) os discursos dos grupos conservadores e os posicionamentos de membros da Arquidiocese; e 3) os estilos de pensamento da edição "Mea Culpa”, ligando-os ao contexto sócio-histórico, político e cultural mais amplo (o que inclui o cotidiano da Arquidiocese). 


\section{Relações entre o Jornal C atólico e a Conjuntura Político- Social Brasileira (1956-85)}

Compreende-se, primeiramente, que a falsificação do semanário configura uma reação de caráter tradicional, embasada por um pensamento reflexivo conservador que dialoga com correntes de pensamento existentes anteriormente, relacionadas aos grupos militares no poder interessados em manter sua continuidade, reagindo, então, a movimentos de caráter progressista, ou seja, que buscam mudanças. As noções sobre correntes de pensamento e visões de mundo também advêm da elaboração conceitual mannheimiana.

Mannheim (1982) dialoga com a sociologia do conhecimento e, a partir desta perspectiva, desenvolve a noção dos chamados estilos de pensamento. Para o autor, existem modos de pensamento cujas origens sociais devem ser buscadas e sua apreensão ocorre pela identificação de sua gênese, desenvolvimento, fusão e desaparecimento. Nesta perspectiva as circunstâncias sociais em mudança são tidas como elementos fundamentais para se pensar tal processo, especialmente no que se refere à objetivação dos grupos e classes sociais, que são os portadores desses estilos de pensamento.

Assim, compreende-se que os indivíduos utilizam-se de "padrões de pensamento" com os quais percebem o mundo. Esses padrões são adquiridos por meio de sua interação com o meio cultural e com os grupos nos quais se inserem (Mannheim, 1981).

Dessa forma, busca-se compreender o pensamento no contexto concreto das situações histórico-sociais, considerando que indivíduos detentores de habilidades reflexivas se inserem em grupos, desenvolvendo um estilo de pensamento particular em uma série de respostas a determinadas situações característica de sua posição comum herdada. 
Nesse sentido, as visões de mundo dos indivíduos, conforme observam Weller et al. (2002), seriam o resultado de uma série de vivências ou experiências ligada à uma mesma estrutura, que se constitui como uma base comum das experiências que perpassam a vida de diversos indivíduos.

Com relação ao JOSP, é importante observar que, diferente de um simples informativo, abarcava em suas publicações tópicos e denúncias que iam além dos assuntos referentes ao cotidiano da Arquidiocese, dos princípios advindos da teologia e dos princípios tidos como primordiais pelos representantes religiosos atuantes nela, abordando temas de interesse político, econômico, social, entre outros. Pereira (1982), em sua obra jornalística, salienta que:

Desde os seus primeiros números é possível notar que o periódico, não obstante uma série de limitações técnicas e financeiras, não seria apenas mais um representante da tradicional "imprensa religiosa" motivada muito mais por preocupações apologéticas e devocionais do que com uma informação séria (Pereira, 1982, p. 146).

De acordo com Lanza (2006), a relevância do semanário não se restringia à região metropolitana de São Paulo, atingindo, também, a esfera nacional e, no decorrer da gestão arcebispal de D. Paulo, houve um grande salto na quantidade de assinantes do JOSP, chegando, em um breve período, a 50 mil exemplares impressos - o que é significativo em relação à abrangência do semanário católico na conjuntura histórica abordada. Ainda, de acordo com o autor, é possível formular uma periodização que é elaborada em termos da gestão arcebispal da Arquidiocese:

(...) o primeiro período, de 1956 a 1966, envolve a fase final do arcebispado de cardeal Motta, quando ocorreu a fundação d'O São Paulo, e parte do arcebispado de cardeal Agnelo Rossi. O segundo período, de 1966 a 1970, representou uma fase de transição entre a predominância conservado- 
ra e uma perspectiva progressista na gestão arcebispal da Arquidiocese de São Paulo, bem como envolveu as discussões oriundas do Concílio Vaticano II, o início das torturas e mortes dos opositores da ditadura militar, entre outras dimensões, coincidindo com a chegada do então bispo auxiliar Dom Paulo Evaristo Arns. 0 terceiro período, de 1970 a 1985, compreende o momento marcado pela ruptura ao apoio dado anteriormente aos governantes militares. Esta etapa esteve em consonância com a nomeação de Dom Arns à condição de arcebispo e cardeal (Lanza, 2006, p. 22).

Considerando-se a questão das divisões internas da própria Igreja de São Paulo, historicamente falando, a partir do Concílio do Vaticano II (1961-1965) e das conferências Episcopais de Medellín (1968) e Puebla (1979), mudou-se o foco de parte do clero da Igreja Católica Latino-Americana, e suas atenções voltaram-se para as massas populares. Tal fato ocasionou divergências no clero católico brasileiro entre:

[...] conservadores liderados pelos bispos da TFP (Tradição Família e Propriedade) - que se posicionaram como partidários da Doutrina que tinha como intuito restaurar os dogmas católicos romanizados centralizando o poder na sede do Vaticano - e progressistas, representados pelo grupo de Dom Hélder Câmara - que apoiaram as camadas populares e combateram os abusos militares durante a ditadura, assim como lutaram pela redemocratização do país (Wanderley, 2007, p. 26-27).

É importante destacar, assim, a existência de uma movimentação dos próprios setores da Igreja Católica (incluindo a Arquidiocese paulistana), que, internamente, apresentavam diferentes orientações em suas formas de interferência sobre a realidade política e social. No Brasil, a igreja popular não consistia em agentes pastorais de base em conflito com a Igreja institucional, ou seja, em conflitos entre a base e a hierarquia, e, sim, envolvia concepções divergentes sobre a missão da Igreja, "cruzando fronteiras entre os grupos leigos, padres, freiras e bispos” (Mainwaring, 2004, p. 10). 
Mesmo antes do golpe militar, existiam tensões entre as orientações de grupos ligados aos catolicismos brasileiros, como foi o caso da Sociedade de Defesa da Tradição, Família e Propriedade ${ }^{6}$ (TFP) e da Ação Popular ${ }^{7}$ (AP). Além desse fator, cabe destacar a existência de diversos processos conjunturais, religiosos, sociais e políticos em determinada fase de seu desenvolvimento, que influíram nas ações desses setores dentro da Igreja Católica, os quais buscavam diferentes formas de intervenção na realidade concreta e possuíam, portanto, um caráter político.

Essas divergências também se fizeram presentes nos arcebispados da Arquidiocese de São Paulo, que não foram homogêneas ${ }^{8}$. Contudo, com movimentos como a Juventude Universitária Católica e a Ação Católica, novos elementos se constituíam historicamente dentro da Igreja de São Paulo; "a orientação institucional [...] passou a aproximar-se de novas perspectivas de atuação, que envolveram de forma especial, a Ação Católica Especializada e as associações operárias católicas" (Lanza, 2006, p. 45), acompanhando, também, mudanças que ocorriam na sociedade.

Essas mudanças, da Igreja Católica no Brasil, resultaram da interação dialética entre agentes pastorais, movimentos leigos e bispos. A base teria desenvolvido importantes inovações que ajudaram a transformar toda a Igreja. Esse movimento tam-

6 Zanotto (2010) observou que a TFP é uma entidade, grupo representativo, ou associação civil, cultural e de caridade/assistência, que operava com base em interesses "conservadores", cujos objetivos expressos eram de colocar-se contra movimentos de esquerda e aqueles que buscassem mudanças identificadas, por seus membros, como prejudiciais para o Estado e a Igreja.

7 Segundo observa Ridenti (1998), a AP surgiu em 1962 como uma organização autônoma, marcada por um romantismo revolucionário, que apresenta uma utopia anticapitalista e objetivava que a humanidade reencontrasse valores e qualidades perdidos com a modernidade, como a doação, a comunidade, harmonia com a natureza, encantamento com a vida, entre outros.

8 Maninwaring (1989) observa que com D. Agnelo Rossi, por exemplo, apesar das críticas às medidas punitivas, houve uma forma de relutância em apresentar posicionamentos críticos à ditadura militar, procurando negar a existência de conflitos entre o Estado e a Igreja, e neutralizando o trabalho de base feito pelos progressistas. 
bém inclui o episcopado, que poderia chegar tanto às dioceses conservadoras, transformando-as sob a liderança de um bispo progressista (Mainwaring, 2004), quanto dificultar a renovação pastoral e outras mudanças, tornando-as praticamente inexequíveis.

No caso da Arquidiocese de São Paulo, a gestão do Cardeal Arns como arcebispo ganhou importância em uma conjuntura na qual, apesar da repressão advinda da gestão autoritária dos sucessivos governos militares, levantaram-se formas de resistência às ações desta natureza. Houve, em setores da Igreja Católica, uma mudança profunda que os fizeram passar a se relacionar com parte da sociedade civil.

\begin{abstract}
Vários movimentos sociais, em defesa dos direitos humanos ou de sindicatos de trabalhadores ou de camponeses, encontraram abrigo sob o guarda-sol protetor da igreja. Através da voz dos bispos, a Igreja criticava, de uma maneira cada vez mais direta e explícita, as violações de direitos humanos e a ausência de democracia. Mas não era só isso: Denunciava também o método de desenvolvimento imposto pelos militares, seu programa de "modernização" em sua totalidade, considerando-o desumano, injusto e baseado na opressão social e econômica dos pobres (Lowy, 2000, p. 145).
\end{abstract}

Como ressalta Rodeghero (2004), do início da década de 1950 até o golpe em 1964 (e posteriormente), alguns setores da Igreja Católica brasileira ligados à Conferência Nacional dos Bispos do Brasil (CNBB) e a grupos de Ação Católica passaram a assumir posições de apoio a lutas e causas populares. Desta forma, críticas ao comunismo ou a aspectos do capitalismo deram lugar ao questionamento da desigualdade e das injustiças sociais.

A Arquidiocese de São Paulo, com o desenrolar desse cenário, esteve envolvida em reformas pastorais e outras atividades progressistas, alavancadas por membros de seu corpo episco- 
pal. Essas reformas possibilitaram o início de comunidades de base na década de 1960 e a promoção de debates que levariam à formação da Pastoral Operária (PO) e movimentos de caráter dinâmico, como a Ação Católica (AC) e a Juventude Operária Católica (JOC), ainda que, de acordo com Mainwaring (2004), até a década de 1970, não houvesse se empenhado ativamente em defender os Direitos Humanos (ONU, 1948) ou expressar as necessidades dos pobres.

A partir de 1970, na Arquidiocese paulistana, ocorreria a ruptura que privilegiou a população da periferia e os perseguidos políticos, fato espraiado nos meios de comunicação da Arquidiocese (Lanza, 2006). Esse fator adquire destaque ao se pensar sua atuação no período político em questão, especialmente na época em que o JOSP foi submetido à censura prévia.

Rezende (1996) destaca a existência de processos na política brasileira que tenderam à exclusão da população do sistema político decisório do país, e sobre a formação de uma peculiar perspectiva democrática no Brasil (e seu posterior esvaziamento), que esteve ligada a determinados grupos e à conjuntura social, histórica, política e cultural na qual estavam inseridos, por exemplo, oligarquias e elites de diferentes composições.

De acordo com Rezende (2013), a ditadura buscou legitimar suas ações galgando sua identificação com a sociedade civil em um combate ao comunismo, proteção da ordem e da moral, desenvolvimento econômico, em nome dos quais desenvolveram-se ações, aparatos e organizações ligadas aos grupos militares com a finalidade de intervir na realidade nacional.

Durante seus primeiros anos, observa Mainwaring (2004), a ditadura tentou construir sua legitimidade ao procurar estabelecer uma ordem social e combater o que, em sua perspectiva, seria a ameaça subversiva. Os quatro primeiros anos do regime se caracterizaram pela oscilação entre propostas de relaxar a 
repressão (preparando o retorno para o governo civil) e a tentativa de instaurar um governo militar que perdurasse. Por fim, em 1968, optou-se pela segunda alternativa, intensificando o processo repreensivo, especialmente após ser decretado o Ato Institucional número 5 (AI-5).

O período se caracterizou pelo endurecimento político do governo Costa e Silva e pela preponderância crescente da linha dura no aparelho de Estado, institucionalizavam-se práticas como a repressão e a tortura, e se delineava "o fechamento do regime e/ ou a centralização do poder que tomou sua forma mais acabada no Governo Médici (1969-1973)" (Rezende, 2013, p. 89).

Foi o contexto de mudanças (como a nomeação de D. Paulo Arns para arcebispo da Arquidiocese de São Paulo e a eleição de D. Aloísio Lorscheider para presidência da CNBB), que "levou a Igreja a uma oposição cada vez mais aberta à ditadura militar" (Lowy, 2000, p.144), delineando um cenário no qual cada vez mais católicos, padres, freiras e bispos passaram a integrar uma forma de oposição à ditadura brasileira.

Dialogando com a noção de "figurações" apresentada por Elias (2006), na qual a sociedade aparece como constituída de numerosos indivíduos que se organizam na forma de "redes", fundamentalmente interdependentes, tributários e dependentes uns dos outros, compreende-se que as ações de D. Paulo à frente da Arquidiocese foram possíveis e potencializadas por fatores conjunturais do período. Esses elementos são relativos às movimentações em voga na época, as quais convergiam para o desenvolvimento de um clima mental que possibilitava diversas manifestações de resistências, tal como foram as publicações do JOSP que sofreram censura prévia.

Com base em tais apontamentos, e nos documentos do arquivo, pôde-se elaborar a perspectiva de que o processo de reflexão, confecção e distribuição do "Mea Culpa" configurou-se, então, 
como uma tentativa de um grupo que, além de comunicar-se com o público leitor do semanário, também se postou contra o conteúdo que vinha sendo publicado no JOSP, divergindo sobre a leitura da situação sócio-política do país apresentada, na época, pelo jornal.

A partir da interpretação dos documentos, apreendeu-se que a falsificação foi acarretada por uma reação tradicional, tendo sua estratégia elaborada com base em um pensamento de caráter conservador, pertencente, portanto, a um grupo de oposição ao que representava o JOSP, na época. Tais fatores evidenciam um movimento por parte desse grupo, que atuaria visando regredir e/ou preservar o contexto político e social instaurado pela ditadura militar. Resistindo, assim, às mudanças em curso no país e utilizando-se do JOSP, e sua abrangência (em termos de público leitor), para difundir os princípios contrários ao conteúdo veiculado pelo semanário até então - assim como alertas sobre a cautela necessária e a forma de lidar com situações e elementos que pudessem contestar tais princípios.

É importante destacar que a ditadura militar procurou legitimar-se através da hipótese da existência de uma "verdadeira democracia" a qual procurava identificar como anseio da população e que, segundo eles, reiterava "os desejos e a mentalidade cristã da sociedade no sentido de preservação do senso de dever e de autoridade" (Rezende, 2013, p. 38). Tal concepção, porém, de acordo com a autora, estava pautada nas perspectivas dos próprios grupos militares no poder e no seu projeto de organização social, procurando-se construir uma ordem social em que se pudesse intervir sobre os indivíduos, grupos e instituições de forma ilimitada e em todos os aspectos.

Apesar desses discursos sobre a democracia, o golpe de 1964 teria representado, para a história política do Brasil, segundo Fernandes (2008), uma contrarrevolução, pois não rompeu com a ordem social estabelecida, dando continuidade a ela, ao po- 
der político da oligarquia burguesa nacional e aos interesses da burguesia externa. Reduziu, ou levou à extinção, os direitos de manifestações contrárias à ordem então estabelecida, além da restrição dos Direitos Humanos (ONU, 1948).

Corresponde a esse movimento uma forma de pensamento que comunga com tais perspectivas e que se empenhava no desenvolvimento de uma mentalidade de caráter harmonioso, a qual rejeitava conflitos e rivalidades entre as diversas classes e grupos sociais, compreendendo,

[...] nos moldes da Escola Superior de Guerra, que a busca de sua legitimidade estaria fundada, consideravelmente, nos elementos psicossociais, os quais se pautavam na criação de valores (e/ou na sublevação daqueles já existentes e que fossem compatíveis com os seus objetivos) condizentes com a nova ordem social que exigia um amplo senso de dever e de refutação de toda e qualquer idéia que pudesse levar ao comunismo (Rezende, 2013, p. 46).

A partir de tais considerações, e da percepção da existência de formas de pensamento que agiam em prol da perpetuação da ditadura militar, e dialogavam, também, com o chamado anticomunismo ${ }^{9}$, percebe-se que o grupo responsável pela idealização, reflexões e elaboração, concretização e distribuição do "Mea Culpa" mantinha interlocuções e orientava suas ações por tais formas de pensamento.

9 Movimento, de caráter sistemático, opositor "ao comunismo ou àquilo que é a ele identificado, $[\ldots]$ que se adapta a diferentes realidades e se manifesta por meio de representações e práticas diversas" (Rodeghero, 2002, p. 464). 


\section{Perspectivas do "M ea Culpa": D iálogos com o Pensamento Conservador Pró-Continuidade da Ditadura M ilitar}

Considerando os apontamentos de Cellard (2012), a análise com fontes documentais procurou classificar o conteúdo da edição falsificada como expressão das visões de mundo de seus autores, de seu diálogo com elementos e correntes de pensamento vigentes na referida conjuntura sócio, histórica, cultural e política, permeada por seus posicionamentos contrários às mudanças em curso (como a abertura democrática).

Na edição cujos falsários declaram, em nome de D. Angélico, possuir um caráter especial ("Mea Culpa”, Nota do Editor, 1982, Lauda 01), destaca-se a suposta releitura e reflexão de D. Paulo sobre suas orientações à Arquidiocese, na qual condena o envolvimento de aspectos políticos em celebrações religiosas, apontando a presença (entre o clero da Arquidiocese de São Paulo) de elementos orientados por princípios caracterizados como "de esquerda" e indicando quais seriam os comportamentos e as orientações que deveriam ser seguidos - assim como quais deveriam ser denunciados e rejeitados. Esses apontamentos foram elaborados de forma que aparecessem relacionados a princípios da própria religião católica, como se ambos se retroalimentassem.

A composição das falas na edição falsificada é o que, primeiramente, se sobressai, visto que procurou "reverter" falas e orientações em voga, até então, na Arquidiocese. Para tal, realiza-se a elaboração de falas em nome do seu clero, por exemplo, as declarações de culpa em nome de D. Paulo, que são apresentadas como resultado de anos de reflexão do mesmo e do reestabelecimento de seu contato com o Espírito Santo e com Deus:

- Minha mensagem representa um Mea Culpa por tudo aquilo que vem acontecendo de errado na igreja do nosso tempo [...] Sinto que uma parcela da igreja procura fazer-se passar 
pelo todo e cada dia avança mais na contestação à própria essência do Catolicismo. 0 marxismo é um sistema de idéias que, por abarcar toda uma concepção da vida e do mundo, mereceu da Igreja a condenação como filosofia. Seus fundamentos são estritamente materialistas: o homem nada vale e Deus não existe perante o marxismo. Não posso aceitar mais que meus irmãos de fé [...] juntem-se aos inimigos da democracia, pois assim agindo, se auto-excomungam (Mea Culpa, 1982, Lauda 01) ${ }^{10}$.

Percebem-se divergências em relação ao conteúdo das publicações não só nos termos empregados, a exemplo de palavras como "subversivo", mas também no foco das publicações, uma vez que a edição falsificada se volta para uma situação específica, ao passo que as publicações do JOSP abrangem diversos tópicos, como, por exemplo, a desigualdade social e econômica entre a população. Tais fatores são evidenciados quando se realiza a leitura das matérias de fato publicadas pelo jornal e que sofreram com a ação da censura prévia' ${ }^{11}$ :

Hoje em dia não é fácil pra ninguém viver - diz o padre muito menos para esse povo do Itaim. É um povo de operários, vive oprimido, trabalhando muito e ganhando pouco, com falta de liberdade [...] E as condições sociais? “O operário - diz o padre - é uma simples peça, uma máquina dentro da indústria (O São Paulo, s/n, s/d, lauda 1) ${ }^{12}$.

Em relação às críticas apresentadas nessas matérias, compreende-se que foram interpretadas, pelos falsificadores do JOSP, como uma forma de buscar mudanças relativas à ordem institu-

10 A instrumentalização de citações das matérias censuradas do jornal "O São Paulo" transcreveu a grafia original dos documentos.

11 As matérias censuradas foram organizadas e digitalizadas através de uma parceria entre o grupo de pesquisa e o NDPH, e podem ser consultadas no site: <http://www.uel. br/grupo-pesquisa/socreligioes/pages/paginas-censuradas-d-o-sao-paulo.php>.

12 A matéria não possui autor, título ou data de produção, e pode ser visualizada no link: <https://drive.google.com/file/d/0BzFtoWP2meSFQXI4d1lEWGtBUkE/view>. 
ída pelo governo ditatorial. Esse elemento coloca em evidência, novamente, o diálogo de interesses correspondentes entre os falsários e os grupos militares no poder, o que compõe, portanto, sua visão de mundo acerca do tema, embasando suas reflexões.

Na matéria intitulada "Subversão crescente na igreja", publicada pelo jornal falsificado, pode-se observar a perspectiva expressa sobre a atuação de membros da Arquidiocese de São Paulo:

Nenhuma advertência [...] tem sido capaz de desviar parte do clero brasileiro, especialmente a CNBB, da aberta pregação político-ideológica de inspiração e identificação nitidamente comunista, à frente os padres mentores das comunidades eclesiais de base, das prelazias [...] (Mea Culpa, Subversão Crescente na Igreja, 1982, Lauda 03).

A citação acima é um indicativo de que seus autores, com base nas matérias do JOSP e nas ações de indivíduos componentes do clero da Arquidiocese, apresentavam preocupações, em relação ao que compreendiam como uma ameaça de caráter comunista, relacionada às orientações políticas que percebiam como "de esquerda", além de alertar aos leitores sobre a necessidade de vigilância. Isto transparece em diversos momentos, inclusive no uso de termos como "besta-fera comuno-socialista" (Mea Culpa, Sejamos Rastreadores, 1982, Lauda 04). Percebe-se, desta forma, a interlocução com correntes de pensamento referentes aos desígnios dos grupos militares, no que se refere a sua "leitura" da situação política e na significação que atribuíam ao regime militar e sua continuidade.

Para compreender a orientação política nomeada como "de esquerda" (e "de direita"), considera-se o que Angelo (2012) observa ser uma polarização cuja origem encontra-se em uma "utopia autoritária" advinda dos militares linha-dura e embasada em um forte componente ético-moral da cultura política considerada de direita e marcadamente anticomunista. 
A concepção de subversão dessa cultura tendeu a identificar as razões da crise de 1964 em uma crise moral supostamente presente na sociedade brasileira, e esses grupos "de direita" almejavam a continuidade da ditadura militar e de sua gestão autoritária (Angelo, 2012). Desta forma, concebiam que partidos políticos, instituições, indivíduos e grupos, cujos princípios e ações divergissem dos ideais e ações ligados à continuidade da ditadura militar e que contestassem os desígnios do princípio de Segurança Nacional, eram considerados "de esquerda", ligados ao comunismo e à subversão da ordem.

A alusão e críticas às orientações políticas denominadas "de esquerda" marcam presença em falas referentes, por exemplo, a rejeição ao que definem como marxismo ou, ainda, no uso de termos opositivos que remetem a passagens bíblicas. As parábolas referidas nos títulos das matérias "Os lobos e o rebanho" (1982, Lauda $\mid 01)$ e "0 joio e o trigo" (1982, Lauda $\mid 04)$ representam um ideário dicotômico (de tipo maniqueísta) que busca denunciar a presença de indivíduos ligados ao comunismo, fomentando o embate ao que definem como o "mal" em meio aos cristãos.

Em leitura da edição apócrifa, percebe-se atribuições valorativas às perspectivas com as quais trabalham, acrescentando avaliações "positivas" ou "negativas" às oposições, que são recursos retóricos utilizados pelos autores. Apreende-se que esse processo evidencia a composição de um discurso que procura estabelecer fronteiras entre a identidade dos autores ("nós") e a identidade dos indivíduos que estariam em um "polo oposto" ("eles"), tal como a convergência destas falas para a identificação do público leitor com o conteúdo do jornal.

Utilizando-se de termos como "católicos", "cristãos", "homens de Deus", "pessoas que buscam a verdade e o bem" para se dirigirem aos leitores e a si mesmos em uma mesma categoria, tal como a alcunha de um "verdadeiro grito de alerta ao povo brasileiro" (Matéria: Mea Culpa, 1982, Lauda 01), o “Mea Culpa” e o 
suposto exame de consciência do cardeal Arns estariam se apresentando, pela primeira vez, sem condicionamentos externos de qualquer espécie. Isto demonstra que seus autores concebiam a existência de "influências" em relação ao conteúdo do JOSP publicado até então, as quais conferem uma "carga negativa", vista, por exemplo, quando observam que as ações de D. Paulo, em acordo com orientações radicais advindas da CNBB, equiparavam-se a "injetar veneno em pequenas doses" (Mea Culpa, 1982, Lauda 01).

Nesse ponto, é necessário apontar a contradição interpretativa que é exposta na edição falsificada em relação aos posicionamentos político-ideológicos defendidos pelo semanário no momento histórico em questão. Neves Jr. (2016) indica que as edições do jornal católico paulistano, no período de censura prévia (1972-78), tendiam à veiculação de estilos de pensamento "reformista-progressista" e "reformista-conservador". Segundo o autor, a equipe editorial proferiu críticas a todo e qualquer tipo de extremismo político (entre eles o comunismo e a própria ditadura militar brasileira).

Outro ponto relevante reside nas constantes críticas proferidas pelo semanário católico, durante a vigência da censura prévia, sobre o efeito nocivo que o extremismo de grupos vinculados ao marxismo apresentava para a realidade político-social brasileira. Apesar de ser reconhecido o valor das contribuições científicas do materialismo histórico-dialético, ressaltava-se a necessidade de limitá-lo aos princípios cristãos de convivência social (Neves Jr., 2016).

Outra perspectiva apresentada na edição apócrifa é a de que as igrejas não deveriam se envolver em questões de âmbito político, e que os membros do clero da Arquidiocese deveriam voltar-se somente a questões de âmbito religioso. Este fato também foi observado em outras elaborações da edição falsificada, quando, em nome de D. Agnelo, afirma-se que a Igreja "não pode 
transformar-se numa instituição política" (Mea Culpa, D. Agnelo critica os que desejam transformar missa em ato político, 1982, Lauda 01).

Tais apontamentos ventilam a possibilidade de que os autores tinham como objetivos, além de expor a presença de indivíduos e religiosos que dialogavam com ideias comunistas nas Igrejas e o suposto tratamento de questões de ordem política no decorrer das missas, principalmente criticar o seu conteúdo, pois as falas de D. Paulo, tal como a orientação que imprimia à Arquidiocese, divergiam dos desígnios e perspectivas desses grupos, sendo, portanto, associadas a influências comunistas.

No texto da edição apócrifa até mesmo os títulos das matérias expressam as concepções de seus autores acerca da "esquerda", à qual associam ideias relativas ao "mal". Por exemplo: "Subversão crescente na Igreja" (Lauda 03) ou, ainda, "Deus é assunto proibido para jovens da URSS" (Lauda 04), o que pode ser um indicativo de que tal ideia foi utilizada para despertar, nos leitores do semanário, a percepção de que aqueles que se envolvem com o comunismo não possuem religião ou fé no Deus cristão, ligando-os a uma representação do diabo, ao que se acrescenta a intenção de associá-los a termos como desobediência silenciosa, discordância explícita e fatores prejudiciais ao bem comum, que são, em sua concepção, desligados do que definem como a essência do cristianismo.

É importante destacar, ainda, que a edição apócrifa faz claras referências à importância de se seguir recomendações e orientações advindas do governo, como, por exemplo, a declaração de que, acreditando nas autoridades e no regime, seria possível possuir uma vida alegre, em paz, e em segurança, sendo este um movimento livre dos comunistas e agitadores (Mea Culpa, 1982, Lauda 02). Além dessa referência, na lauda 04, é fornecida uma listagem com recomendações sobre como se portar/agir/pensar em convergência com o governo militar: 
1. Cooperar com o trabalho do governo na solução dos problemas nacionais, de qualquer ordem, de modo a facilitar a tarefa governamental; de seus familiares e amigos;

2. Prestigiar as ações cívicas, com apelos aos sentimentos patrióticos

3. Informar, sem constrangimento e sem rodeio, às autoridades, aquilo que lhe parecer suspeito e contra os interesses nacionais;

4. Conhecer adequadamente as manhas e os procedimentos esquerdistas, bem como difundir esse conhecimento;

5. Ter convicção quanto ao perigo vermelho no mundo e, em particular, no brasil;

6. Admitir que a expectativa e a passividade poderão ser funestas;

7. Acreditar na igual responsabilidade de civis e militares, de governantes -e governados, quando se trata de salvaguardar a integridade e soberania nacionais;

8. Lutar pela paz e tranquilidade, não se contentando ou limitando-se a desejá-las;

9. Crer, convictamente, que a democracia é condição essencial para a realização da justiça social e capaz de permitir o desenvolvimento almejado;

10. Enfim, cumprir seus deveres como cidadão brasileiro, em sua plenitude (Mea Culpa. Ações políticas. 1982, Lauda 04).

A partir da citação, ressalta-se a elaboração reflexiva da edição falsificada em diálogo com tais concepções conservadoras, que visavam à continuidade da ditadura militar, objetivo dos autores da versão apócrifa.

As diretrizes citadas na listagem das ações políticas, no documento acima, ainda são qualificadas pelos autores da edição apócrifa como deveres do cidadão brasileiro, o que reforça a concepção de organicidade da nação com os princípios militares da política autoritária de Segurança Nacional. Tudo o que estivesse fora desses princípios deveria ser afastado, vigiado, denunciado ou até mesmo eliminado.

Portanto, a interpretação, com base nas fontes documentais, possibilitou a identificação do envolvimento de grupos que dialogavam 
com elementos político-ideológicos de vertentes do anticomunismo e apresentou a discordância dos autores em relação às ações do clero progressista. A partir desta exposição, desenvolve-se no próximo item a análise dos distintos estilos de pensamento que estiverem presentes no processo de confecção do "Mea Culpa".

\section{O s "Estilos D e Pensamentos" Identificados na Edição Apócrifa}

A partir dos cinco estilos básicos de pensamento na perspectiva mannheimiana, foi possível distinguir a presença de diferentes ideais político-ideológicos na edição "Mea Culpa”, que, apesar de expressarem divergências em determinados fatores, tinham um objetivo comum: a articulação política conjunta para combater e desqualificar os ideais político-ideológicos do catolicismo libertador vinculados no jornal "O São Paulo".

A primeira vertente identificada é a concomitante com a ideologia militar de segurança nacional, nomeada "reformista conservadora". Entende-se que os princípios desse estilo de pensamento são sintetizados na filosofia política de Golbery do Couto e Silva (2003), sendo difundidos nos distintos setores da sociedade brasileira por meio da doutrina de Segurança Nacional da Escola Superior de Guerra (ESG) ${ }^{13}$.

O protagonismo dessa vertente na edição "Mea Culpa” evidencia-se por sua presença na nota de abertura, "Um exame de consciência”, de suposta autoria do próprio D. Paulo Evaristo Arns. Em sua falsa confissão, o cardeal afirmaria:

13 A doutrina de Segurança Nacional encontra sua gênese nas dependências da Escola Superior de Guerra, instituição construída sob moldes diretivos da National War College (EUA), que tinha como principal objetivo a formação de uma elite civil-militar, ideologicamente coesa, para o combate das iminentes ameaças decorrentes da divisão dicotômica do mundo - dentre os ideólogos da instituição superior, destacou-se o general Golbery do Couto e Silva (Garcia, 1997; Miguel, 2002; Mundim, 2007; Fernandes, 2009). 
Atuei de forma insidiosa, conscientizando lentamente, injetando veneno em pequenas doses, subliminarmente, nos cursilhos, nas reuniões de comunidades de base, nas missas, através dos sermões, das palestras, dos boletins paroquiais, do semanário "O São Paulo" e até mesmo dos cânticos, numa verdadeira lavagem cerebral, e usando o Evangelho e a imagem de Cristo como camuflagem e, às vezes, a batina como escudo.

Expus teoria das relações entre capital e trabalho de inspirações nitidamente marxista, tornei-me tributário das intenções e dos planos mais prejudiciais ao bem comum dos cristãos e de todo o povo (Mea Culpa, 1982, Lauda 01).

Nota-se, pois, a ilustração do indivíduo subversivo como peçonhento, ardiloso, estrategista e maligno, assim como a exposição da ideia de infiltração dos elementos comunistas em meio à instituição religiosa. Esses dois elementos remontam ao princípio de "guerra total" - conceito fundamental para a ideologia golberyana, que presumia a extensão do âmbito da guerra, em decorrência do desenvolvimento tecnológico, afirmando que a disputa deveria abarcar também os campos político, econômico e psicossocial (Miguel, 2002).

Dessa forma, desenvolve-se a percepção de correntes do marxismo que se infiltram estrategicamente nas instituições públicas e privadas da sociedade ocidental, ambicionando corromper as mentes despreparadas ("lavagem cerebral") para eclodir com as bases orgânicas da democracia cristã ocidental.

Assim, a defesa da noção de "planos prejudiciais ao bem comum dos cristãos e de todo povo" remonta à perspectiva da doutrina golberyana que pressupunha o inexorável embate entre o "ocidente cristão democrático e o oriente ateu comunista", o qual demandaria a extensão da preocupação com a segurança nacional para todos os cidadãos brasileiros - membros de um país geneticamente cristão e ocidental (Silva, 2003). 
Dentro dessa perspectiva, destacam-se duas matérias expostas na quarta e última laudas da edição apócrifa, "Sejamos Rastreadores" e "Ações Políticas" - nenhuma das duas apresenta autoria. Enquanto a primeira se incumbe de apresentar as principais características de um sujeito subversivo, conclamando os cidadãos a se autovigiarem ostensivamente, a segunda ocupa-se em definir as qualidades cabíveis a um cidadão realmente cristão e patriota.

Além de convergirem para a proposta de ampliação da atribuição de vigilância em defesa da Segurança Nacional, também corroboram a universalização de uma noção subordinada e acrítica de participação política. Essa ideia também é desenvolvida na matéria "O filho do homem veio buscar e salvar o que se havia perdido"14, a qual afirma:

Não atendemos mais à insinuação diabólica de falsos padres, capetas vermelhos. Não entraremos no caminho tenebroso da perdição que leva à morte. Hoje passamos a acreditar. Acreditamos nas autoridades e no governo, para vivermos alegres, em paz, seguros. Nosso movimento está livre dos comunistas e agitadores (Mea Culpa, 1982, Lauda 02).

Para Fernandes (2008), essa percepção conservadora de direcionamento político é uma das principais características do modelo político-econômico que se desenvolve na sociedade brasileira, em decorrência da relação de dependência/subordinação do capitalismo nacional ao capital hegemônico. Por consequência, não foi permitida a ampliação da participação política popular, quando os movimentos sociais progressistas ameaçaram a manutenção da ordem.

Portanto, pode-se inferir que, por parte desses grupos, seguindo a lógica de suas oposições e dicotomias, não agir de acordo com os desígnios dos grupos militares no poder conduziria à tristeza, 
desordem e insegurança, o que é novamente citado quando, no tópico “Ações Políticas" (1982, Lauda 04), são fornecidas orientações para cooperar com o trabalho do governo, estar atento e denunciar o "perigo vermelho", proteger a integridade e a soberania nacional.

A primeira vertente do pensamento identificada pela pesquisa está, portanto, vinculada às ideias que representaram a doutrina de Segurança Nacional da Escola Superior de Guerra. Se, por um lado, esse estilo de pensamento preconizava a necessidade de desenvolver o país, por outro, limitava este processo ao âmbito econômico, não prevendo nem a ampliação da participação política, nem o desenvolvimento social, reforçando, ainda, a perspectiva de subordinar o desenvolvimento à planificação estatal, com ênfase no protagonismo diretivo do estamento militar.

A partir dessa constatação podemos classificar os supostos envolvidos no processo de elaboração e falsificação da edição do jornal "O São Paulo", como vinculados a um "estilo de pensamento reformista-conservador", ao passo em que se visa um processo altamente controlado de desenvolvimento que possibilite a continuidade das rígidas estruturas político-sociais do país. Indicam, ainda, a presença de elementos do "tradicionalismo" no processo de fundamentação das ideias - tais como o maniqueísmo religioso e a ilustração do comunismo como uma força anticristã.

A partir da pesquisa documental que se construiu nas matérias da edição "Mea Culpa”, foi identificado outro estilo de pensamento nomeado como conservador tradicional inspirado na base político-ideológica-integrista (TFP). Assim, contradizendo alguns elementos básicos da visão de mundo que correspondiam à doutrina de Segurança Nacional, a matéria "A pregação de Boff", por exemplo, expressou as seguintes críticas ao teólogo da libertação ${ }^{15}$ :

15 Leonardo Boff foi um dos principais teóricos da Teologia da Libertação no Brasil, tendo sido membro da Ordem dos Frades Menores (franciscanos). 
Sua afirmação de que de que todos possuem os seus contrários, direita e esquerda, norte, sul, quente, frio, para deduzir de que o Espírito Santo é um [sic] Síntese, A la Hegel (ou A la Marx), é uma grande tolice que só servirá aos seus obscuros propósitos em relação à Igreja ou ao seu vedetismo que os seus seguidores basbaques chamam de carisma (?) (Mea Culpa, 1982, Lauda 02 - grifos nossos).

0 não-reconhecimento da existência da subversão como elemento histórico inexorável da convivência humana e a crítica ao método dialético hegeliano são incongruentes com a filosofia militar de Golbery do Couto e Silva - à qual se propõe reconhecer que a subversão surge em determinados períodos históricos como resultado das distorções políticas de elites egoístas e oportunistas (Silva, 2003).

Analisando a matéria, percebeu-se a negação das contribuições da dialética à interpretação da sociedade, o que evidenciou ligações com as correntes reacionárias e conservadoras da Igreja Católica ${ }^{16}$.

Segundo Pierucci (1992), configura o pensamento integrista de Plínio Corrêa, o principal grupo de reação católica das décadas de 1960 a 1980 (TFP), que se destacou pela capacidade de mobilização popular apartidária, expondo uma pressuposição de divisão entre poder secular e religioso.

Em continuidade a essa lógica de pensamento, na matéria "Subversão crescente na Igreja" encontram-se apontamentos que indicam a recusa desse grupo frente à apropriação de elementos da modernidade por parte das parcelas do clero brasileiro. Destaca-se o seguinte trecho:

16 Para maior aprofundamento, ver o "ultramontanismo", corrente que propunha a negação da modernidade, em maior ou menor medida, conclamando a recentralização dos poderes nas mãos do papado, que deteria o monopólio da interpretação dos textos sagrados (Miceli, 2009). 
Na verdade, à pompa e à circunstância que marcavam a Liturgia da missa, católica nos tempos hoje tachados de "triunfalistas" pelas correntes libertadoras, sucedeu um momento evolutivo em que simplicidade substituiu o fausto e em que o violão ou outros instrumentos da cultura popular tomaram o lugar do órgão. Era, dizia-se, a identidade, pela música da Igreja com os pobres... Da substituição do órgão pelo violão e do coral pelo atabaque, contudo, passou-se rapidamente para a transformação da Liturgia para confundir a celebração da missa com a pregação político-doutrinária, para aproveitar a reunião de fiéis com o objetivo de separá-los, cindi-los em dois grupos distintos e irreconciliáveis: os pobres, do povo de Deus, e os outros (Mea Culpa, 1982, Lauda 03 - grifos nossos).

0 trecho citado, além de reforçar o combate clerical aos elementos da modernidade (apropriação da cultura popular e teorias seculares), indica a linha de raciocínio típica desses grupos de reação católica, que consiste na consideração do processo de secularização como linha construtora do socialismo. Nessa visão de mundo o liberalismo seria o princípio de um longo processo de destruição da sociedade cristã, que encontraria seu fim com a ascensão do socialismo/comunismo (Miceli, 2009).

Identifica-se, pois, que o segundo grupo em destaque no processo de falsificação da edição do jornal católico paulistano, que identificamos como inspirado na base político-ideológica-integrista (TFP), caracteriza-se por um estilo de pensamento primordialmente "conservador", com fortes traços influenciais do "tradicionalismo" - enquanto reação que engatilha a articulação político-social deste grupo em prol da conservação de padrões de convivência social.

É importante destacar que, a despeito do engajamento de órgãos públicos nas investigações em busca dos responsáveis pela elaboração e distribuição do "Mea Culpa" e dos percalços e entraves burocráticos entre os departamentos ${ }^{17}$, os resultados da investigação

17 Departamento Estadual de Ordem Política e Social de São Paulo (DEOPS) e posteriormente o Departamento de Ordem Política e Social (DOPS) mineiro. 
progrediram graças à participação ativa do advogado contratado pela cúria metropolitana de São Paulo, José Carlos Dias ${ }^{18}$. Por meio de um informante, o advogado chegou à gráfica (Perez e Bovolenta Serviços Gráficos e Ltda.) onde tinha sido impressa a edição.

A partir dos depoimentos dos proprietários da gráfica, pôde-se chegar aos outros envolvidos. Dias acompanhou as investigações, inclusive comparecendo à primeira visita à gráfica. Contudo, a Arquidiocese ainda teria contratado outro advogado em Minas Gerais, o deputado federal (pelo PMDB) José Edgar de Amorim, para acompanhar o desenrolar dos depoimentos e investigações ${ }^{19}$.

Existe, ainda, um terceiro grupo que foi identificado na análise das matérias veiculadas na edição "Mea Culpa”, que possuía como característica o pensamento liberal, contrário ao "gigantismo estatal" e à ausência de um capitalismo "verdadeiro" no Brasil. Em menor proporção que os demais, expressa sua vertente de pensamento em apenas uma das matérias, intituladas "Um peso duas idéias", na qual se afirmou que:

Agora, sabemos qual o pecado que pretendem abolir no País, pois, antes, não estava muito evidente para nós de que tipo de regime capitalista falavam as notas da CNBB e as pregações de d. Balduíno, de d. Pedro Casaldáliga, do padre Suess e de outras figuras exponenciais do nosso clero progressista. Quando se referiam ao Brasil como um país capitalista, não conseguíamos enxergar onde estaria localizado o tal capitalismo, uma vez que temos, na verdade, um Estado burocrático e oligopólico que procura impedir, a todo custo, o advento do verdadeiro capitalismo entre nós (Mea Culpa, 1982, Lauda 04).

É perceptível nesse trecho a elaboração de uma crítica que ultrapassou os limites do combate à Teologia da Libertação (que aqui

18 Dias era ex-presidente da comissão de justiça e paz da Arquidiocese de São Paulo. 19 Essas informações foram retiradas das fontes documentais referentes à reação midiática, que constam no dossiê disponibilizado pela Arquidiocese de São Paulo. 
é ilustrado nas figuras de d. Tomás Balduíno ${ }^{20}$, d. Pedro Casaldáliga $^{21}$ e padre Suess ${ }^{22}$ ) e estende-se, em menor medida, à crítica do sistema político-econômico brasileiro em sua totalidade.

Note-se, pois, a afirmação de que o Brasil nunca atingiu o capitalismo "verdadeiro" por conta do exercício do poder estatal altamente "burocrático e oligopólico". A afirmação contraria os anseios dos grupos militares no período, assim como os princípios da doutrina da ESG, que se preocupava em vincular sua imagem diretiva ao processo de desenvolvimento econômico $^{23}$.

Ao mesmo tempo, a proposição de construção de uma sociedade capitalista que supere o estado de coisas da época é incongruente com o pensamento integrista, porque pressupõe o rompimento com os padrões de convivência política e social da sociedade brasileira, em vez de buscar sua conservação.

Assim, essa terceira vertente político-ideológica identificada na edição apócrifa torna-se a mais complexa e contraditória para a análise do estilo de pensamento. Por um lado, ela demonstra alguns elementos do "conservadorismo" e, em contrapartida, o texto conclama a transformação das relações de produção e o rompimento com o modelo de domínio estatal vigente, fator que indica tendências a um "reformismo progressista".

$20 \mathrm{Na}$ época d. Balduíno estava vinculado à Arquidiocese de Goiânia. Tinha como principal enfoque de sua luta do catolicismo libertador as temáticas da reforma agrária e das questões indígenas.

21 D. Casaldáliga exercia o cargo de bispo de São Félix do Araguaia, participando ativamente do processo de luta pelos direitos humanos, defesa de uma politização democrática popular e processos missionários indígenas (sem colonização).

22 Paulo Suess era secretário do Conselho Indigenista Missionário (CIMI), estando vinculado principalmente ao estado Amazonas.

23 Nesse sentido, Giannazi (2013) discute as relações decorrentes da perspectiva desenvolvimentista, que permeou a doutrina de Segurança Nacional, e o momento histórico que ficou conhecido como "milagre econômico". 
Indica-se, portanto, que essa terceira vertente pode ser classificada como potencialmente "reformista-progressista" no que tange o âmbito econômico, com fortes tendências ao "reformismo-conservador" quando abrange os campos político e social - tendo em vista que o desenvolvimento econômico não implicaria, necessariamente, em uma melhor distribuição de renda ${ }^{24}$.

0 reconhecimento dessas três vertentes político-ideológicas no processo de falsificação da edição do jornal católico "O São Paulo" evidencia a multiplicidade de interesses dos distintos grupos da direita em descredenciar as formulações e ações político-sociais da Teologia da Libertação, com ênfase no meio de comunicação da Arquidiocese paulistana.

\section{Considerações finais}

Pode-se inferir a partir dos estudos sobre o "Mea Culpa" (1982) que as elaborações de seus autores buscam meios de alcançar o reconhecimento da ordem social instituída pelo golpe militar de 1964, e de suas ações e medidas totalitárias, entre os diversos segmentos sociais grupos, instituições e indivíduos. Assim como observa Rezende (2013), essa busca não ocorre somente no âmbito legal e através de legislações, mas também de uma forma que se identificassem seus objetivos e interesses com os da população mais ampla, procurando relacioná-los à sua noção de ordem social, como sendo um produto dos anseios da maioria da população.

24 Reconhecemos que a escassez de material vinculado ao grupo para análise do pensamento limita as contribuições expostas neste trabalho, principalmente no que tange à identificação de um grupo específico ao qual o autor se vinculava na conjuntura da época. 
Entre outros fatores, o estudo das matérias publicadas na versão "Mea Culpa” do jornal “O São Paulo" evidenciou a manutenção da ditadura militar e a uma estratégia de cunho político por parte dos falsificadores, que consistia em silenciar os debates promovidos pelo clero progressista, definidos como "liturgias ridículas" no âmbito católico.

Apreendeu-se, portanto, que tais elaborações têm como base - em sua maioria - um pensamento de caráter conservador, e possibilitaram a identificação de elementos pertencentes aos diferentes estilos de pensamento elencados por Mannheim, o "estilo de pensamento reformista conservador", um primordialmente "conservador", com fortes traços do "tradicionalismo", e o "reformista-progressista".

Pode-se ainda perceber que seus autores buscaram comunicar-se com os leitores do JOSP e semear confusões e questionamentos em relação ao clero progressista, tendo em vista a abrangência do semanário e a possibilidade de diálogo a respeito dos debates que emergiam nas edições semanais e buscavam consolidar a redemocratização em sua publicação.

Além da discordância ideológica que foi evidenciada em relação às ações do clero progressista, apontadas na edição falsificada como subversivas, pode-se inferir que um dos objetivos da falsificação seria não só contestar debates em voga no conteúdo do semanário, ou presentes nas orientações de D. Paulo à Arquidiocese, mas também orientar como agir frente ao que identificavam como ameaças à ordem instituída, o que é significativo em termos de seus diálogos com as correntes de pensamento ligadas ao grupos militares, sua gestão autoritária e em relação à conjuntura que vivenciavam, de abertura e mudanças políticas.

Por fim, é importante observar, em relação ao grupo envolvido no processo de elaboração, falsificação e distribuição do "Mea Culpa", 
que a interpretação das fontes documentais a partir da conceituação mannheiniana apontou a possibilidade de inferir a participação e a caracterização de um grupo liberal no processo ${ }^{25}$.

\section{Ref erências}

Angelo, Vitor Amorim de. Ditadura militar, esquerda armada e memória social no Brasil. 2011. 225 f. Tese (Doutorado em Ciências Humanas) - Universidade Federal de São Carlos, São Carlos, 2011.

Cellard, André. A análise documental. In: Poupart, Jean et al. A Pesquisa Qualitativa: Enfoques epistemológicos e metodológicos, $3^{\circ}$ ed. Rio de Janeiro: Petrópolis, Editora Vozes, 2012, p. 295-316.

Elias, Norbert. 0 sociólogo como destruidor de mitos. In: Introdução à Sociologia. Lisboa, Ed. 70, 1999, p. 53-75.

Processos de formação de Estados e construção de nações. In: Nobert Elias, Escritos e Ensaios 1 - Estado, Processo e Opinião Pública. Rio de Janeiro: Jorge Zahar Editor: 2006, p. 153-165.

Fernandes, Ananda S. "A reformulação da Doutrina de Segurança Nacional pela Escola Superior de Guerra no Brasil: a geopolítica de Golbery do Couto e Silva". Antíteses, Londrina, vol. 2, núm. 4, jul-dez, 2009, p. 831-856.

Fernandes, Florestan. A Revolução Burguesa no Brasil: ensaio de interpretação sociológica. 5a ed. São Paulo: Editora Globo, 2008.

Fonseca Junior, Wilson Corrêa da. Análise de Conteúdo. In: Duarte, J., Barros, A. (org.). Métodos e técnicas de pesquisa em comunicação. 2 Edição. São Paulo: Atlas, 2011.

Garcia, Eugênio V. 0 pensamento dos militares e a política externa (19611989). Revista Brasileira de Política Internacional, Brasília, 40 (1), p. 1840, 1997.

Giumbelli, Emerson. Para além do "trabalho de campo": reflexões supostamente malinowskianas. Rev. bras. Ci. Soc. [online]. 2002, vol.17, n.48, p .91-107.

Giannazi, Carlos. A doutrina de segurança nacional e "milagre econômico" (1969/1973). São Paulo: Cortez Editora, 2013.

25 Contudo, esses são dados novos para o processo de investigação e que serão posteriormente desenvolvidos em pesquisa. 
Lanza, Fabio. Matrizes Ideológicas dos Arcebispos Paulistanos (195685): Um olhar sob o prisma do semanário o São Paulo. 2006. Tese (Doutorado) em Ciências Sociais apresentada a Pontifícia Universidade Católica de São Paulo.

Mainwaring, Scott. Igreja Católica e política no Brasil (1916-1985). São Paulo: Brasiliense, 2004.

Mannhein, Karl. “O pensamento conservador”. In Martins, J. S. (org.) Introdução crítica à sociologia rural. São Paulo: Hucitec, 1981.

Mannheim, Karl. Abordagem Preliminar do Problema. In: Mannheim, K. Ideologia e Utopia. Rio de Janeiro: Zahar Editores, 1982, p. 29-60.

Miceli, Sérgio. A Elite Eclesiástica Brasileira. São Paulo: Companhia das Letras, 2009.

Miguel, Luis F. "Segurança e desenvolvimento: peculiaridades da ideologia da segurança nacional no Brasil”. Diálogos Latinoamericanos, Århus, n. 5, 2002, p. $40-56$.

Mundim, Luiz F. C. Juarez Távora e Golbery do Couto e Silva: Escola Superior de Guerra e a organização do Estado brasileiro. Dissertação de Mestrado em História.

Neves Jr, José Wilson Assis. Novas fontes para compreender a censura prévia militar: uma análise do arquivo censurado do jornal católico O São Paulo (1972-78). 2016. Dissertação (Mestrado) em Ciências Sociais, Universidade Estadual de Londrina.

ONU - Organização das Nações Unidas. Declaração Universal dos Direitos Humanos. 1948. Disponível em: http://unesdoc.unesco.org/ images/0013/001394/139423por.pdf

Pereira, Antônio Aparecido. A Igreja e a Censura Política à Imprensa no Brasil 1968- 1979: com particular atenção à censura ao semanário arquidiocesano “O São Paulo”. 1982. Tese (Doutorado) em Jornalismo, apresentada ao Centro Internazionale per gli Studi sull'Opinione Pubblica, Roma.

Pierucci, Antônio Flávio. Fundamentalismo e integrismo: os nomes e a coisa. Revista USP, São Paulo, v.13, março-maio, p. 144-156, 1992.

Rezende, Maria José de. A democracia no Brasil: um confronto entre as principais perspectivas teóricas na primeira metade do século XX. Revista Mediações, Londrina, v. 1, n. 1, p. 33-44, 1996.

Rezende, Maria José de. A Ditadura Militar no Brasil: Repressão e Pretensão de legitimidade 1964-1984. Londrina: Editora UEL, 2013. 
Ridenti, Marcelo. 0 romantismo revolucionário da Ação Popular: do cristianismo ao maoísmo. Preparado para apresentação na reunião de 1998 da Latin American Studies Association - SM014, The Palmer House Hilton Hotel, Chicago, Illinois, Setembro, 1998.

Rodeghero, Carla Simone. Religião e patriotismo: o anticomunismo católico nos Estados Unidos e no Brasil nos anos da Guerra Fria. Revista Brasileira de História, São Paulo, v. 22, n. 44, p. 463-488, 2002.

Rodrigues, Raíssa Regina B. Permanências do Conservadorismo Brasileiro no Processo de Redemocratização na Década de 1980: estudo d’O São Paulo e da Edição Falsificada Mea Culpa. Londrina, 2018.

Santos, Vitor Garcia Rodrigues dos. Caso Riocentro: Terror e violência no processo de abertura política brasileiro. Revista Contemporânea. Niterói, Ano 4, v.1, n. 5, p. 1-27, 2014

Silva, Golbery do Couto e. Geopolítica e Poder. Rio de Janeiro: UniverCidade, 2003.

Souza, Luiz Alberto Gómes de. As várias faces da Igreja Católica. Estudos Avançados, São Paulo, v. 18, n. 52, p. 77-95, dez. 2004.

Wanderley, Luiz Eduardo Wanderley. Democracia e Igreja Popular. São Paulo: EDUC, 2007.

Weller, Wivian et al. Karl Mannheim e o método documentário de interpretação: uma forma de análise das visões de mundo. Sociedade e Estado. Brasília, v. 17, n. 2, p. 375-396, Dez. 2002.

Zanotto, Gizele. Tradição, família e propriedade (TFP): um movimento católico no Brasil (1960-1995). Lócus: revista de História, Juiz de Fora, v. 30, n.1 p. 87-101, 2010. 


\section{DOCUMENTOS CENSURADOS DO “O SÃO PAULO”}

OSP.

$\left[\mathrm{s} / \mathrm{n},-\right.$ de -, lauda 01] ${ }^{26}$.

26 Essa matéria não possui autor declarado, título ou data de produção. 0 documento pode ser visualizado no link: <https://drive.google.com/file/ d/0BzFtoWP2meSFQXI4d1lEWGtBUkE/view>. 